\title{
Enzyme and membrane markers in leukaemia: recent developments
}

\author{
AV HOFFBRAND AND G JANOSSY \\ From the Departments of Haematology and Immunology, The Royal Free Hospital, London, UK
}

SUMmARY Terminal deoxynucleotidyl transferase (TdT) assay has proved a valuable test for distinguishing lymphoblastic from myeloblastic leukaemias, particularly in adults whose blast cells are often negative for the c-ALL antigen. The immunofluorescence assay, particularly when used in combination with antisera to surface membrane antigens, has proved a sensitive technique for detecting small numbers of lymphoblasts in extramedullary sites, for example, testis or cerebrospinal fluid, or of residual Thy-ALL blasts in the marrow, which might otherwise be difficult to recognise.

Differences in concentrations of several enzymes concerned in purine metabolism have been detected between the blast cells in the various acute leukaemias. Adenosine deaminase (ADA) concentrations tend to be higher in Thy-ALL than in other forms of leukaemia, but the wide overlap reduces the diagnostic value of this assay. Thy-ALL blasts, however, appear to be selectively and exquisitely susceptible to inhibition of ADA by the drug deoxycoformycin, which has now been used sucessfully in a number of otherwise resistant patients with Thy-ALL to obtain a complete remission.

The recently introduced technique for the production of monoclonal antibodies has substantially widened the reagents available for analysing the membrane characteristics of bone marrow stem cells and of cell lineages derived from them. These have revealed previously unsuspected heterogeneity among different cases of acute lymphoblastic leukaemia, for example, among Thy-ALL blasts from different patients, and they have also delineated minor populations of immature thymocytes from which these leukaemic cells are derived. The potential use of these antibodies to prevent graft-versus-host disease by selective removal of $\mathrm{T}$-lymphocytes from donor bone marrow before allogeneic bone marrow transplantation, or to prevent recurrence of Thy-ALL and other lymphoblastic leukaemias or lymphomas by selective removal of leukaemic or lymphoma malignant cells before autologous transplantation, is reviewed.

During the last three years enzymatic and immunological assays have been used concomitantly in our laboratory for the characterisation of leukaemic cells and their normal counterparts. This study has evolved partly from our long-term interest in DNA metabolism of haemopoietic cells ${ }^{1}$ and has been initiated partly by the extensive characterisation of membrane structures (cALL antigen and Ia-like antigens) on leukaemic cells and their normal equivalent cells in Dr MF Greaves' laboratory at the Imperial Cancer Research Fund. ${ }^{2}$ Both avenues were greatly facilitated by the fact that large numbers of leukaemic samples have been made available for diagnostic testing through the MRC UKALL trials organised by Dr HEM Kay. The aims of these studies have always been threefold: (1) accurate diagnosis $;^{3-5}$ (2) elaboration of reagents and test systems for the study of normal cells from which the various forms of acute lymphoblastic leukaemia (ALL) originate ${ }^{6}$ and (3) standardisation of new avenues for leukaemia treatment. ${ }^{78}$ An important advance in concomitant enzymatic and immunological analysis had taken place when Dr FJ Bollum developed a specific antibody to nuclear terminal deoxynucleotidyl transferase (TdT). ${ }^{9}$ By combining the analysis of nuclear TdT and membrane markers in double colour immunofluorescence tests, the immunoenzymatic analysis of individual single cells has become feasible. ${ }^{10}$ The method is both simple and important since these double marker assays prove useful in the efficient analysis of new specific 'monoclonal' antibodies (made by somatic cell hybridisation in mice) on even minute haemopoietic cell subpopulations, which helps to standardise anti- 
bodies for potential therapeutic use.

In our short account of enzyme markers below, it was expedient to include the relevant membrane marker observations (Table). In the second part of the study, some of these immunological aspects are further discussed in greater detail. In this review we concentrate on advances made in the last three years. There have been a number of recent major reviews in this field. ${ }^{2} 611-13$

Panel of reagents for leukaemia diagnosis*

\begin{tabular}{|c|c|c|}
\hline Antibody to: & Made in: & $\begin{array}{l}\text { References below and } \\
\text { availability }\end{array}$ \\
\hline $\begin{array}{l}\text { Terminal } \\
\text { deoxynucleotidyl } \\
\text { transferase (TdT) }\end{array}$ & Rabbit $†$ & $\begin{array}{l}\text { 1, 2; Bethesda } \\
\text { Research Labs }\end{array}$ \\
\hline Ia-like (p28, 33) & $\begin{array}{l}\text { Rabbit } \\
\text { Chicken } \\
\text { Monoclonal (mouse } \\
\text { and rat) }\end{array}$ & $\begin{array}{l}\text { 3, 4, 5; Alpha-Gamma } \\
\text { Labs, USA } \\
2 \text { 6; Sera Labs, UK, } \\
\text { and other firms }\end{array}$ \\
\hline $\begin{array}{l}\text { Common ALL } \\
\text { (cALL) antigen }\end{array}$ & $\begin{array}{l}\text { Rabbit } \\
\text { Monoclonal (mouse) }\end{array}$ & $\begin{array}{l}7,8 \\
9\end{array}$ \\
\hline $\begin{array}{l}\text { Human } T / \text { thymic } \\
\text { lymphocyte antigen } \\
\text { (HuTLA) }\end{array}$ & $\begin{array}{l}\text { Rabbit } \\
\text { Monoclonal (mouse) }\end{array}$ & $\begin{array}{l}2,3,10 ; \text { other } \\
\text { laboratories } \\
11,12\end{array}$ \\
\hline $\begin{array}{l}\text { Human thymocyte } \\
\text { antigen }\end{array}$ & Monoclonal (mouse) & 12, 13; Sera Labs, UK \\
\hline Human IgM & Goat $\dagger$ & $\begin{array}{l}2,14 \text {; other } \\
\text { laboratories }\end{array}$ \\
\hline
\end{tabular}

*Due to lack of space only some of the relevant references are shown. $\dagger$ These reagents are pure antibodies eluted from the relevant immunoadsorbent column.

${ }_{1}^{1}$ Bollum FJ. Proc Natl Acad Sci USA 1975;72:4119

2 Janossy G, et al. J Immunol 1979;123:1525

${ }^{3}$ Schlossman SF, et al. Proc Natl Acad Sci USA 1976;73:1288

4 Billing R, et al. J Exp Med 1976;144:167

${ }^{5}$ Winchester RJ, et al. Proc Natl Acad Sci USA 1977;74:4012

- Charron D, et al. Blood 1979;54 Suppl. 1:82a

${ }^{7}$ Greaves MF, Janossy G. Biochem Biophys Acta 1978;516:193

${ }^{8}$ Billing R, et al. $J$ Natl Cancer Inst 1978;61:423

- Ritz J, et al. Nature 1980;283:583

10 Touraine JI, et al. Clin Exp Immunol 1974;16:503

${ }^{11}$ Kung PC, et al. Science 1979;206:347

12 Reinherz E, et al. Proc Natl Acad Sci 1980;77:1588

13 McMichael AJ, et al. Eur J Immunol 1979;9:205

14 Gathings WE, et al. Eur J Immunol 1977;7:804

\section{Enzyme markers}

A wide range of enzyme analyses is now available which may be used to distinguish different forms of leukaemia. These may be detected by cytochemical, biochemical, immunofluorescence, or electron microscopic techniques. In this section we wish to concentrate on terminal deoxynucleotidyl transferase (TdT, E.C. 2.7.7.31), which has proved particularly valuable in distinguishing lymphoblastic from myeloblastic leukaemias, and two enzymes in purine interconversion, adenosine deaminase (ADA, E.C. 3.5.4.4) and purine nucleoside phosphorylase (PNP, E.C. 2.4.2.1), which not only have diagnostic value but also have therapeutic implications, particularly for the treatment of thymic(Thy)-ALL.
TERMINAL DEOXYNUCLEOTIDYL TRANSFERASE

\section{Analysis of normal cells}

Although the enzyme was detected in thymus by Bollum in 1962, it was only in 1973 that McCaffrey et al. reported a raised level in c-ALL blasts and aroused clinical interest (reviewed by Bollum ${ }^{11}$ ). Two normal human tissues, bone marrow and thymus, are now known to contain the enzyme. Immunofluorescent studies using a rabbit anti-TdT antibody ${ }^{9}$ have shown that a small fraction of normal bone marrow cells resembling normal lymphocytes are TdT positive. These cells are also usually positive for Ia-like and c-ALL antigens (Fig. 1). None of the $\mathrm{TdT}^{+}$cells in the marrow show $\mathrm{T}$-cell surface markers or surface membrane immunoglobulin (SmIg), that is, these cells are non-T, non-B. ${ }^{10}$ The number of $\mathrm{TdT}^{+}$cells is increased in regenerating marrow, for example, after chemotherapy or bone marrow transplantation.

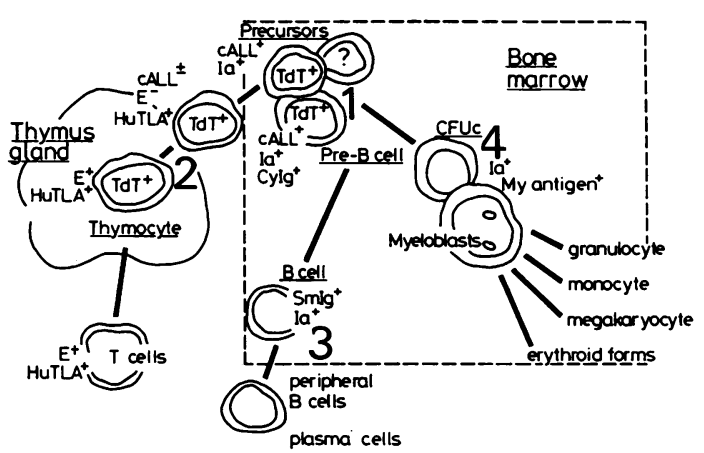

Fig. 1 The main leukaemic phenotypes and the corresponding normal precursor cell types. The reagents used are shown in the Table. Note that normal TdT ${ }^{+}$ pre-B cells (cytoplasmic immunoglobulin positive) are extremely rare while approximately $30 \%$ of common $A L L$ cases are pre-B $\left(\mathrm{TdT}^{+}, \mathrm{CyIgM^{+ } )}\right.$.

1 Common ALL and pre-B ALL: both are $C A L L$ antigen $^{+}, \mathrm{Ia}^{+}, \mathrm{TdT}^{+}, \mathrm{SmIg} \mathrm{I}^{-}, \mathrm{HuTLA} \mathrm{A}^{-}, \mathrm{My}$. In addition, pre-B ALL blast cells have cytoplasmic IgM.

2 Two forms of thymic ALL: both are $\mathrm{HuTL} \mathrm{A}^{+}, \mathrm{TdT} \mathrm{T}^{+}$, $\mathrm{Ia}^{-}, \mathrm{SmIg}-, \mathrm{My}^{-}$. The rare 'early' forms are $\mathrm{E}^{-}$and weakly $c A L L^{+}$; the typical Thy-ALL is $E^{+}, c A L L^{-}$. $3 \mathrm{~B}-\mathrm{ALL}: \mathrm{SmIg}^{+}, \mathrm{Ia}^{+}, \mathrm{TdT}^{-}, \mathrm{E}^{-}, \mathrm{HuTLA} \mathrm{A}^{-}, \mathrm{My}^{-}, \mathrm{CALL} L^{-}$. 4 AML: $\mathrm{My}^{+}, \mathrm{Ia}^{+}, \mathrm{TdT}^{-}, \mathrm{E}^{-}, \mathrm{HuTLA} \mathrm{A}^{-}, \mathrm{SmIg}^{-}, \mathrm{cALL} \mathrm{L}^{-}$ ?: The phenotypic characteristics and leukaemic equivalents of the human pre-lymphoid, pre-myeloid pluripotential stem cells are unknown.

A few pre-B cells of $\mathrm{TdT}^{+}, \mathrm{Cy}$ (cytoplasmic) $\mathrm{IgM}^{+}$, Sm (surface membrane) $\mathrm{Ig}^{-}$phenotype can also be observed in normal child marrow but their number is extremely low: only $1 \%$ of the marrow $\mathrm{TdT}+$ 
population. The vast majority of normal pre-B cells $\left(\mathrm{CyIgM}^{+}, \mathrm{SmIg}^{-}\right)$in the marrow are $\mathrm{TdT}-{ }^{10}$ In spite of their rarity, the finding of a small proportion of cells with an intermediate phenotype between $\mathrm{cALL}^{+}, \mathrm{TdT}^{+}, \mathrm{SmIg}^{-}$cells (marrow precursors?) and the $\mathrm{CALL}^{-}, \mathrm{TdT}^{-}, \mathrm{SmIg}^{+}$lymphocytes (bone marrow B cell) tentatively suggests that these cells could belong to the same differentiation lineage. ${ }^{14}$

Cell separation studies have shown that the $\mathrm{TdT}^{+}$ cell is not in the fraction containing CFUc or BFUe, but whether the pluripotential stem cell (CFUs in mouse) is $\mathrm{TdT}^{+}$is unknown. In the rat, a proportion of $\mathrm{TdT}^{+}$cells develop $\mathrm{T}$ cell (thymocyte?) characteristics when treated with thymosin. 1516

In the human thymus, the $\mathrm{TdT}^{+}$cells are predominantly localised in the cortex, while the majority of medullary thymocytes (which express characteristics of peripheral $\mathbf{T}$ lymphocytes) are $\mathrm{TdT}^{-}$. No $\mathrm{TdT}^{+}$cells can be detected in circulating blood and peripheral lymphoid organs, apart from the transitional appearance of a low proportion of $\mathrm{TdT}^{+}$cells in young animals (eg, 1-4-week-old rats). ${ }^{17} \mathrm{The} \mathrm{TdT}^{+}$ thymic cell develops in rat, chicken, and human in late fetal life before $\mathrm{TdT}^{+}$bone marrow cells can be detected. In the mouse, it can also be shown that the $\mathrm{TdT}^{+}$bone marrow cell arises independently of the thymus, for example, in athymic 'nude' animals. ${ }^{18}$

In man, cortical thymocytes and peripheral $T$ cells carry HuTLA membrane antigens (detected by heterologous antisera) but do not express Ia-like antigens. Therefore cortical thymocytes are $\mathbf{T d T}^{+}$, HuTLA $^{+}, \mathrm{Ia}^{-}$, and peripheral $\mathrm{T}$ cells are $\mathrm{TdT}^{-}$, $\mathrm{HuTLA}^{+}, \mathrm{Ia}^{-}$.

\section{Studies in leukaemia: Acute lymphoblastic \\ leukaemia}

Approximately $95 \%$ of patients with CALL (positive with the antiserum described by Greaves) have $\mathrm{TdT}^{+}$ blast cells. ${ }^{341319}$ The expression of the enzyme assessed by biochemical assay or by immunofluorescence is extremely variable, enzyme levels in positive cases ranging from 3.0 to $>200$ units $/ 1^{8}$ cells. In most but not all cases, cALL and Ia-like antigens are also expressed (Fig. 1). In older children and adults, however, cALL antigen is often negative and then TdT is a particularly valuable marker. Patients with cALL who are TdT $^{-}$are usually young children and infants, but the response to therapy and prognosis does not appear to differ from that of the more usual $\mathrm{TdT}^{+}$cases.

A subgroup of cALL exhibit $\mathrm{TdT}^{+}$blasts with cytoplasmic IgM (Cy IgM; pre-B ALL). $2021 \mathrm{We}$ emphasise that in other respects these pre-B blast cells have the cALL phenotype $\left(\mathrm{cALL}^{+}, \mathrm{Ia}^{+}, \mathrm{TdT}^{+}\right)$ and frequently contain mixtures of Cy IgM negative and positive blasts. These findings suggested that leukaemic cells in some cases of cALL undergo at least a partial lymphocyte differentiation into pre-B cells. As these pre-B blasts do not express surface membrane immunoglobulin they are different from typical B-ALL leukaemic blasts or normal B cells which are $\mathrm{CALL}^{-}, \mathrm{TdT}^{-}, \mathrm{SmIg}^{+}$. (Interestingly, very few leukaemias, if any, contain mixtures of $\mathrm{TdT}^{+}$, $\mathrm{CyIgM}^{+}, \mathrm{SmIg}^{-}$, pre-B and $\mathrm{TdT}^{-}, \mathrm{CyIgM}^{-}, \mathrm{SmIg}^{+}$ B blasts.)

As the blast phenotype in cALL is similar to that of the normal marrow $\mathrm{TdT}^{+}$cells $\left(\mathrm{TdT}^{+}, \mathrm{Ia}^{+}, \mathrm{cALL}^{+}\right)$ individual residual or relapsing cALL blasts in the bone marrow suspension from treated patients can not yet be detected. The presence of $\mathrm{TdT}^{+}$cells at extramedullary (and extrathymic) sites may, however, indicate leukaemia. Thus immunofluorescence studies with anti-TdT on cells in the cerebrospinal fluid can be used to detect blasts that might otherwise be missed, ${ }^{22}$ while both immunoperoxidase and immunofluorescence studies may be used to detect $\mathrm{TdT}^{+}$testicular infiltration (Fig. $2^{2324}$ ).

Thy-ALL blasts are also usually $\mathrm{TdT}^{+}$but this leukaemia is $\mathrm{HuTLA}^{+}, \mathrm{Ia}^{-}$. In normal or regenerating bone marrow, no $\mathrm{TdT}^{+}$, HuTLA ${ }^{+}$cells can be detected, and in the marrow of patients treated for Thy-ALL even a single $\mathrm{TdT}^{+}, \mathrm{HuTLA}^{+}$cell indicates residual leukaemia. This assay is obviously more sensitive than conventional haematological methods. ${ }^{24}$

Acute myeloblastic leukaemia

Over $95 \%$ of cases are $\mathrm{TdT}^{-}$. The few $\mathrm{TdT}^{+} \mathrm{Ph}^{\prime}-$ negative cases show mixtures of lymphoblastic and myeloblastic leukaemia, or there is aberrant expression of TdT on myeloblasts. ${ }^{25}$ In some studies, cases with a myelomonocytic pattern $\left(\mathbf{M}_{4}\right)$ appear to be more likely to be $\mathrm{TdT}^{+}{ }^{26}$ Our own studies suggest that these $\mathrm{TdT}^{+}$cases tend to be older and have a worse prognosis than is usual in AML and do not respond well to therapy for either ALL or AML. It is not yet clear whether these mixed cases consist of two separate clones or a single clone diverging along separate differentiation pathways.

These $\mathrm{TdT}^{+}$cases of AML must be distinguished from cases of undifferentiated leukaemia in which the cells evade characterisation by morphological and cytochemical techniques. A positive TdT test in such cases implies, in our experience, a lymphoblastic origin and good response to vincristine and prednisone.

Chronic granulocytic leukaemia

$\mathrm{TdT}^{+}$cells are not found in the peripheral blood or bone marrow in the chronic phase but about onethird of typical $\mathbf{P h}^{\prime}$-positive cases of CGL in acute transformation show $\mathrm{TdT}^{+}$blasts, and in some, but not all, cases these blasts show other typical morpho- 


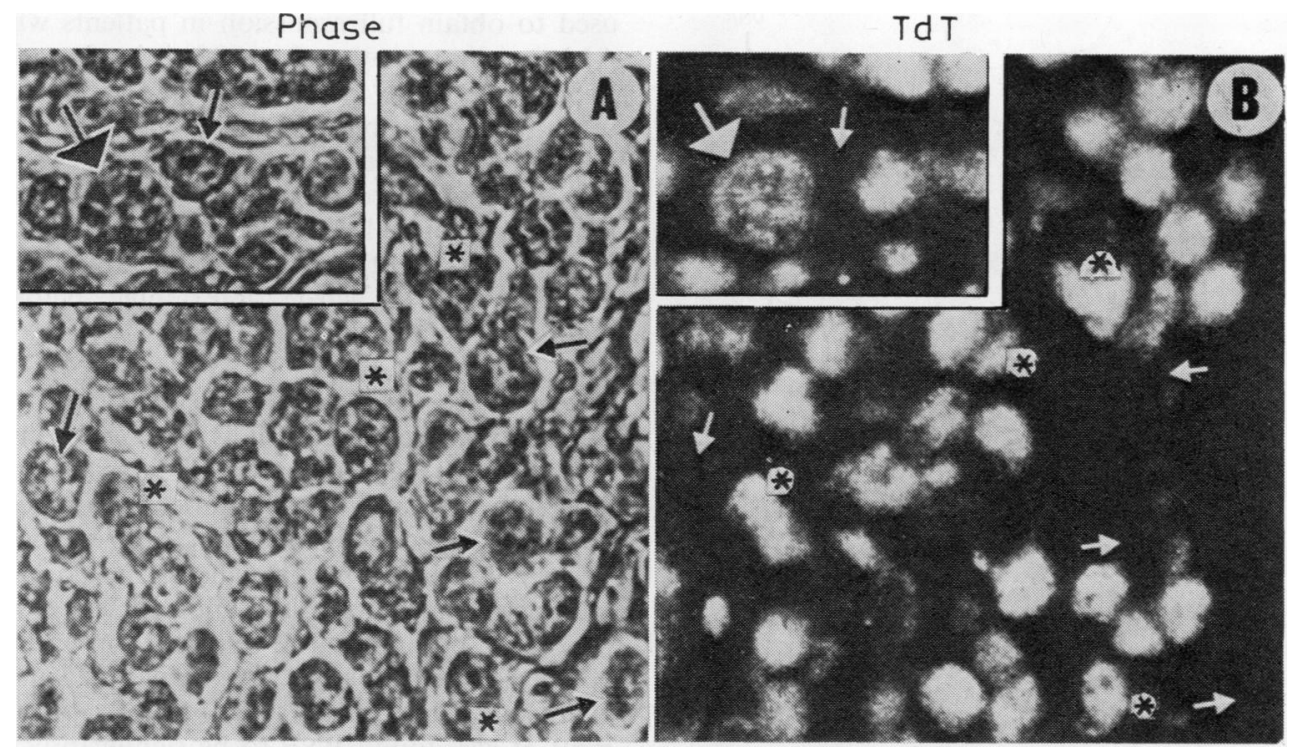

Fig. 2 Detection of terminal deoxynucleotidyl transferase in leukaemic blast cells infiltrating the testis. Sections from the formalin-fixed testis were stained with anti-TdT and fluorescein-labelled second layer $(F I T C)(B)$. The pha se contrast appearance of the same area is shown $(A)$. Asterisks show blasts that have an irregular nucleus; the TdT stain is clearly nuclear. Large arrow points to a dividing cell where the TdT is released into the cytoplasm. Small arrows point to TdT-blast cells. ${ }^{22}$

logical and cytochemical features of lymphoblasts. $\mathrm{Ph}^{\prime}$-negative cases may also show this $\mathrm{TdT}^{+}$lymphoblastic transformation, and in some cases the blasts show pre-B features. ${ }^{27} \mathrm{TdT}^{+}$cases show a substantially better response to chemotherapy for ALL (vincristine and prednisone) and longer survival than those in myeloblastic transformation. ${ }^{28}$

\section{CLL and lymphomas}

TdT is negative in chronic B and T cell disorders, including the tumour cells in CLL, Sézary's syndrome, mycosis fungoides, Hodgkin's disease, and most non-Hodgkin's lymphomas. In a few histologically diffuse and poorly differentiated lymphomas, TdT is positive, and in these cases, where the appropriate tests have been carried out, the cells show T-cell markers. ${ }^{29} 30$

\section{ADENOSINE DEAMINASE}

The importance of this enzyme in lymphoid development has been recognised since the observation that congenital ADA deficiency was a cause of T-cell deficiency. ${ }^{31}$ ADA is concerned in the degradation and recycling of purines, converting deoxyadenosine and adenosine to deoxyinosine and inosine, respectively (Fig. 3). Although the enzyme is present in most body cells, the highest concentration occurs in thymic cortical cells, ${ }^{32}$ and the concentration is higher in mature $\mathrm{T}$ than $\mathrm{B}$ cells. Thymocytes and $\mathrm{T}$ cells are more susceptible to deoxyadenosine toxicity because they have a lower ability to degrade deoxyadenosine triphosphate (dATP) than B cells or other tissues, the $5^{\prime}$ nucleotidase level being particularly low while they have high levels of deoxynucleoside kinases. ${ }^{33-35}$ Taheri et al. ${ }^{36}$ have shown that Thy-ALL cells, unlike other cells, are unable to compartmentalise dATP into a degradative pool. Accumulation of dATP is thought to inhibit ribonucleotide reductase in $T$ cell precursors and thus switch off the supply of dTTP, dATP, and dCTP and so inhibit DNA synthesis. An alternative suggested mechanism of toxicity in ADA deficiency is the accumulation of S-adenosyl-homocysteine (SAH) due to inhibition of SAH hydrolase by adenosine with inhibition of Sadenosyl methionine (SAM) synthesis and thus reduced methylation of RNA, DNA, and proteins. ${ }^{37}$

Recent studies in patients treated with the ADA inhibitor, deoxycoformycin (dCF), show that the rise in dATP rather than inhibition of SAH hydrolase correlates with cell killing. ${ }^{38}$

\section{$A D A$ in leukaemia}

Initial studies showed raised levels in acute leukaemia, whether myeloblastic or lymphoblastic, ${ }^{39} 40$ and levels in CLL lower than in normal peripheral blood. ${ }^{42}$ More recently, the incidence of raised 


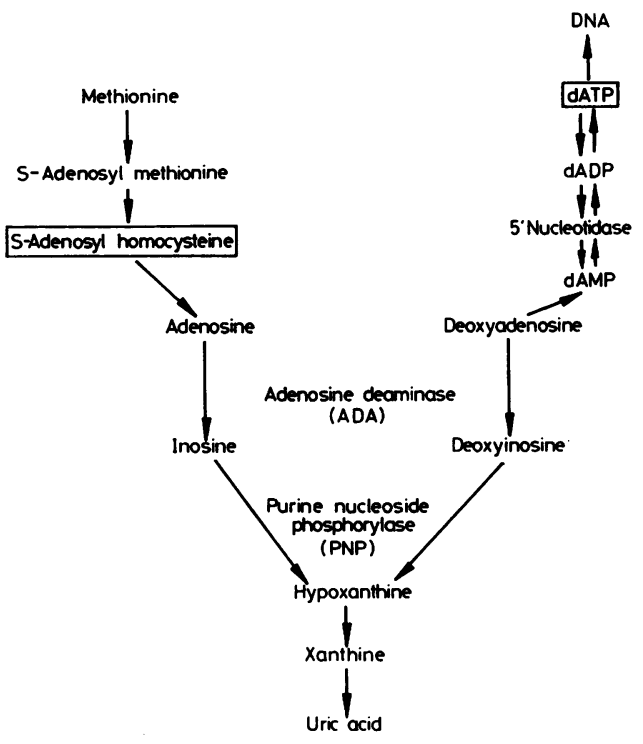

Fig. 3 The role of adenosine deaminase $(A D A)$ and purine nucleoside phosphorylase (PNP) in metabolism of purines. PNP also degrades deoxyguanosine and guanosine to guanine. Toxicity due to ADA deficiency (or inhibition) is thought to be due to accumulation of dATP with inhibition of ribonucleotide reductase and also to accumulation of $S$-adenosyl homocysteine, whereas PNP deficiency leads mainly to deoxyguanosine and dGTP accumulation (not shown): $d A=$ deoxyadenosine; $M P, D P, T P=m o n o-, d i-$, and tri-phosphate respectively.

levels has been shown to be higher in ALL than in AML, the highest levels occurring in Thy-ALL blasts. ${ }^{4344}$ An antibody to the enzyme may be used in a radioassay of enzyme in cells or serum, and this has confirmed enzyme assays showing particularly high levels in Thy-ALL blasts. The assay may have value in confirming remission or demonstrating early relapse since the serum level appears to relate to total body ADA level.45

The diagnostic value of the enzyme assay is, however, limited. Although Thy-ALL blasts tend to show higher ADA and lower TdT concentrations than CALL blasts, ${ }^{4346}$ the overlap is too great for reliable distinction. Similarly, although, in the chronic lymphoid proliferative disorders, ADA is higher in the T-cell tumours (Sézary's syndrome, T-CLL or T-prolymphocytic leukaemia) than in B-cell disorders, the overlap is again substantial. ${ }^{46}$ The observation that deoxycoformycin, an ADA inhibitor, inhibits T-cell proliferation ${ }^{47}$ and may be used to obtain full remission in patients with ThyALL resistant to other drugs, ${ }^{838} 48$ is of considerable importance. The action seems to be extremely selective, CALL blasts proving resistant to ADA inhibition. ${ }^{38} 49$ The drug is also of value in patients with the more chronic T-cell disorders in selectively killing tumour cells (Prentice et al., in preparation). It also has potential value for selective removal of Thy-ALL cells in vitro, for example, before autologous transplantation. ${ }^{8}$

Purine nucleoside phosphorylase (PNP) (E.C. 2.4.2.1) This enzyme acts sequentially with ADA in purine degradation (Fig. 3), converting inosine or deoxyinosine hypoxanthine and guanosine or deoxyguanosine to guanine. Congenital deficiency of PNP, either complete or partial, due to the presence of a mutant enzyme causes immune deficiency with lack of T-cells but normal B-cell function ${ }^{50}$ which has been ascribed to the accumulation of deoxyguanosine and dGTP in T-cell precursors. ${ }^{51}$ Blatt et al. ${ }^{52}$ found PNP to be significantly reduced in eight cases of Thy-ALL (range 10-100U, median 38) compared with 14 cases of non-T, non-B ALL (range 50-140U, median 79) or compared with normal peripheral blood mononuclear cells (range 10-230U, median 83).

On the other hand, cytochemical staining has suggested that it is the T-cells in peripheral blood that are PNP positive and B-cells negative with decreased activity in B-CLL compared to norma peripheral blood. ${ }^{53} 54$

\section{Immunological markers in leukaemia}

It has been emphasised above that many of the new immunological reagents (anti-TdT, anti-ALL, antiIa-like, anti-HuTLA, and anti-myeloid antisera) play complementary roles in the differential diagnosis of leukaemias. The diagnostic accuracy can therefore be increased when the reagents to mem- 의 brane antigens are used in combination with each other or with an antiserum detecting nuclear TdT 음 enzyme (see above and ref. 10). An even more recent development has been the standardisation of new $\mathrm{Gr}$ monoclonal antibodies (McAb-s). Many of these $N$ McAb-s react with the same molecules as the conven- N tional reagents (cALL antigen, Ia-like antigens, $O$ sheep erythrocyte receptor on thymocytes and Tcells, etc). The great advantages of the McAb-s are that no absorptions are required during their prep- $\stackrel{\oplus}{\rightarrow}$ aration, and they can be made in large amounts for wide distribution and general use in many labora- $\bar{O}$ tories. It is therefore likely that the McAb-s will $\mathbb{D}$ replace many of the conventional reagents in $\bar{D}$ leukaemia analysis. 
RECENT DEVELOPMENTS IN MEMBRANE

MARKER ANALYSIS

As McAb-s can be distributed widely, the initial standardisation of the product frequently takes place in many different collaborating laboratories, some of which use functional assays for lymphocyte subsets ${ }^{55}$ and analysis on the cell sorter and cytofluorograph. ${ }^{55-57}$ In our laboratory, two groups of assays have been used for analysing the reactivity of McAb-s. The first group has been analysis of bone marrow precursor cells. This included (1) reactivity of $\mathrm{TdT}^{+}$cells (putative lymphoid precursors) with $\mathrm{McAb}$; (2) reactivity of recognisable myeloblasts (identified by morphology and staining for Ia-like antigens); and (3) the CFUc activity in vitro after separating the positive and negative populations on the cell sorter. ${ }^{58}$ The second group of tests has been the analysis of differentiating cells: thymocytes/T cells, B lymphoid cells, and myeloid/erythroid cells. For this, well-established known antisera (antiHuTLA, anti-Ig, anti-myeloid, etc) were used in double combination with the new McAb, and the phase contrast morphology of the cells was also studied.

\section{MONOCLONAL ANTIBODIES REACTING WITH} MARROW PRECURSORS

Five interesting reagents fall into this group. The two most obvious ones are: the new $\mathrm{McAb}$ reacting with the cALL antigen, ${ }^{59}$ which labels only normal $\mathrm{TdT}^{+}$ marrow cells; and McAb-s to Ia-like antigens, which label $\mathrm{TdT}^{+}$marrow cells and, in addition, myeloblasts, CFUc cells, and B lymphocytes but not thymocytes/T cells and differentiating myeloid/ erythroid cells. ${ }^{60}$

A new McAb (RFB-1, made by DrM Bodger at the Royal Free Hospital) labels $\mathrm{TdT}^{+}$marrow cells, myeloblasts, and CFUc (but not differentiating myeloid/erythroid cells) and $\mathrm{TdT}^{+}$thymocytes (but not $T$ cells). This reagent is unreactive with $B$ lymphocytes. In contrast, the BA-2 (standardised by Dr J Kersey's group) labels only $\mathrm{TdT}^{+}$marrow cells and B lymphocytes. Finally, the OKT10 reagent is an antibody made by Ortho Laboratories, which reacts with precursor cells of all haemopoietic lineages: $\mathrm{TdT}^{+}$marrow cells, marrow B lymphocytes, myeloblasts, and CFUc and $\mathrm{TdT}^{+}$thymocytes, but is unreactive with differentiating and mature cells of the marrow peripheral $\mathrm{T}$ and $\mathrm{B}$ lymphocytes. ${ }^{61}$

In conclusion, $\mathrm{a}$ new range of $\mathrm{McAb}-\mathrm{s}$ recognise abundantly expressed membrane structures (evidenced by bright immunofluorescence staining) which are present on marrow precursors and seem to be 'spreading down' on immature cells of the various differentiation pathways to a different degree. These essentially morphological observations have to be interpreted with caution. Clearly, cell separation techniques combined with cell culture and new functional assays are now required for the exact analysis of the reactivity of these new reagents. Using these principles in the rat, a remarkable purification of the various haemopoietic precursor cells could be achieved with the help of anti-Thy-1 antibody. ${ }^{62}$ This anti-rat antibody seems to have a reactivity pattern similar to that of the anti-human McAb OKT10. Nevertheless the group of assays used here already provides sufficient indications about the expected diagnostic and potential therapeutic uses of the reagents studied (see below).

\section{MONOCLONAL ANTIBODIES REACTING WITH}

DIFFERENTIATING CELLS

A wide range of McAb-s is now available which react with thymocytes and $T$ lymphocytes. These studies confirm that Thy-ALL has a thymic origin. As the McAb-s have a finer analytical capacity than conventional antibodies, the new observations reveal more details: Thy-ALL blast cells closely parallel the phenotypic characteristics of a relatively minor, probably immature subpopulation of larger thymic blast cells. ${ }^{6364}$ Thus only some of the McAb-s react with most Thy-ALL blast cells strongly, for example, pan-T reagents such as OKT11 made by Ortho, Lyt-3 made by Kamoun et al., ${ }^{65}$ and T101 prepared by Royston et al. ${ }^{66}$ Many other McAb-s (which are strongly reactive against normal cortical thymocytes); for example, NA1/34 made by McMichael et al. ${ }^{67}$ and OKT4, 5, 6, and 8 described by Reinherz et al. ${ }^{63}$ frequently detect only small proportions of Thy-ALL blasts present in the sample. ${ }^{63}$ 64 It will therefore be interesting to see whether additional McAb-s can be made which react only with normal large thymic blast cells (and the majority or all of corresponding Thy-ALL blast cells).

Particular attention has to be focused on the McAb-s reacting with peripheral $T$ lymphocytes. These include OKT3 (which reacts with all TdT- $^{-}$ $\mathrm{HuTLA}^{+}$cells in the bone marrow, peripheral blood, and lymphoid organs), and pan-T reagents (OKT11, Lyt-3, see above, or UCHT1 standardised by Beverley and colleagues). The important point is that these antibodies are apparently unreactive with marrow precursors such as $\mathrm{TdT}^{+}$cells $^{61}$ and CFUc. ${ }^{58}$

Other McAb-s reacting with differentiating cells of B cell, myeloid, erythroid, monocyte lineage have been described 68 but are outside the scope of our study.

POTENTIAL USE OF MCAb-S IN LEUKAEMIA TREATMENT

The two main areas are (1) the removal of mature $T$ lymphocytes from the allogeneic bone marrow 
before transplantation (prevention of graft versus host disease: GvHD) and (2) elimination of residual leukaemic cells from the autologous bone marrow without damaging marrow stem cells.

Since McAb-s reactive with $T$ lymphocytes are available, and some of these are lytic in the presence of rabbit complement (eg, OKT3), ${ }^{56}$ it will be important to establish the best method to prevent GvHD (coating of $T$ cells with antibody? lysis of $T$ cells in vitro? removal of $\mathrm{T}$ cells on immunoabsorbents?). These studies are in progress.

Once the techniques of $\mathrm{T}$-cell removal are perfected the elimination of residual leukaemic blasts can also be attempted. The obvious candidates are patients with Thy-ALL (eg, using antibody OKT11), B lymphoma, and perhaps cALL in second remission. The removal of $\mathrm{TdT}^{+}$putative lymphoid precursors together with the residual cALL blasts may not have serious consequences ${ }^{69}$ although it remains to be seen whether the surviving patients develop hypogammaglobulinaemia.

\section{Conclusions}

Chemotherapy alone dramatically improved survival in leukaemia. Remission induction is successful in most patients but many relapse. Additional therapy is required. This needs to be selective with no or only minimal additional myelotoxicity. A better understanding of the enzymatic and antigenic make-up of leukaemic cells may lead to selective treatment protocols. It is already clear that ADA inhibitors kill Thy-ALL blasts selectively, and it may be that during the course of marrow transplantation the antibodies used will remove $\mathbf{T}$ cells or residual Thy-ALL blasts specifically without damaging myeloid stem cells. These efforts should be used in combination with conventional therapy and with each other. Allogeneic bone marrow transplantation may already be the choice of therapy for AML, and the studies described here can only improve the prospect of patients with AML, ALL, and other leukaemias.

We are grateful to our many colleagues who have co-operated in many of the studies reported from our laboratories, in particular, Dr HG Prentice, Dr KF Bradstock, Dr K Ganeshaguru, Dr S Papageorgiou, Dr D Crawford, Dr GE Francis, Dr N Russell, Dr N Lee, Dr A Piga, Dr M Bodger, Mr N Tidman, and Mrs S Granger. Our work has been supported by grants from the Medical Research Council, the Leukaemia Research Fund, the Wellcome Trust, and the North-East Thames Region of the National Health Service.

\section{References}

${ }^{1}$ Hoffbrand AV, Ganeshaguru K, Hooton JWL, Tripp E. Megaloblastic anaemia: initiation of DNA synthesis in excess of DNA chain elongation as the underlying mechanism. Clinics in Haemat 1976;5:727-45.

${ }^{2}$ Greaves MF. Clinical applications of cell surface markers. Progress in Haematol 1975;9:255-303.

${ }^{3}$ Hoff brand AV, Ganeshaguru K, Janossy G, Greaves MF, Catovsky D, Woodruff RK. Terminal deoxynucleotidyltransferase levels and membrane phenotypes in diagnosis of acute leukaemia. Lancet 1977;2:520-3.

4 Janossy G, Hoffbrand AV, Greaves MF, et al. Terminal transferase enzyme assay and immunological membrane markers in the diagnosis of leukaemia - a multiparameter analysis of 300 cases. Br J Haematol 1980;44:221-34.

${ }^{5}$ Greaves MF, Janossy G, Peto J, Kay HEM. Immunologically defined subclasses of acute lymphoblastic leukaemia in children: their relationship to presentation features and prognosis. $\mathrm{Br} \mathrm{J} \mathrm{Haematol}$ in press.

- Greaves MF, Janossy G. Patterns of gene expression and the cellular origins of human leukaemias. Biochim Biophys Acta 1978;516:193-230.

? Janossy G, Prentice HG, Bradstock KF, Hoffbrand AV. Recent advances in the diagnosis and treatment of thymic acute lymphoblastic leukaemia. In: Serrou B, Rosenfeld C, eds. New trends in human immunology and cancer immunotherapy. New York: Academic Press, 1980.

${ }^{8}$ Prentice HG, Smyth JF, Ganeshaguru K, et al. Remission induction with adenosine inhibitor $2^{\prime}$ deoxycoformycin in Thy-lymphoblastic leukaemia. Lancet 1980;2:170-2.

9 Bollum FJ. Antibody to terminal deoxynucleotidyl transferase. Proc Natl Acad Sci USA 1975;72:4119-22.

10 Janossy G, Bollum FJ, Bradstock KF, McMichael A, Rapson N, Greaves MF. Terminal transferase positive human bone marrow cells exhibit the antigenic phenotype of non-T, non-B acute lymphoblastic leukaemia. $J$ Immunol 1979;123:1525-9.

11 Bollum FJ. Terminal deoxynucleotidyl transferase as a hematopoietic cell marker. Blood 1979;54:1203-15.

12 Catovsky D. Leucocyte enzymes in leukaemia. In: Roath S, ed. Topical reviews in haematology, Vol. 1. Bristol: Wright, 1980;157-85.

${ }^{13}$ Hoff brand AV, Ganeshaguru K, Llewellin P, Janossy G. In: Gross R, Hellriegel KP, eds. Biochemical markers in leukaemia and lymphoma. Berlin: Springer Verlag, 1979; 25-39.

14 Janossy G, Pizzolo G. Differentiation of lymphoid precursor cells. J Clin Pathol 1979;32 :Suppl.13.

15 Goldschneider I, Metcalf D, Battye F, Mandel T. Analysis of rat hemopoietic cells on the FACS 1. Isolation of pluripotent hemopoietic stem cells and granulocytemacrophage progenitor cells. J Exp Med 1980;152: 419-37.

${ }^{16}$ Pazmino NH, Ihle JN, Goldstein AL. Induction in vivo and in vitro of terminal deoxynucleotidyl transferase by thymosin in bone marrow cells from athymic mice. J Exp Med 1978;147:708-18.

${ }^{17}$ Gregoire KE, Goldschneider I, Barton RW, Bollum FJ. Ontogeny of TdT positive cells in lymphohemapoietic tissues of rat and mouse. J Immunol 1979;123:1347-57.

${ }^{18}$ Hutton JJ, Bollum FJ. Terminal deoxynucleotidyl transferase is present in athymic nude mice. Nucleic Acids Res $1977 ; 4: 45-8$.

19 Hutton JJ, Coleman MS, Keneklis TP, Bollum FJ. Terminal deoxynucleotidyl transferase as a tumor cell marker in leukemia and lymphoma: Results from 1000 patients. Adv Med Oncol Res and Educ 1979;4:165-75. 
${ }^{20}$ Vogler LB, Crist WM, Bockman DE, Pearl ER, Lawton AR, Cooper MD. Pre-B cell leukemia: a new phenotype of childhood lymphoblastic leukemia. New Engl J Med 1978;298:872-8.

${ }^{21}$ Greaves M, Verbi W, Vogler L, et al. Antigenic and enzymatic phenotypes of the pre-B subclass of acute lymphoblastic leukaemia. Leuk Res 1979;3:353-62.

${ }^{22}$ Bradstock K, Papageorgiou ES, Janossy G, Hoffbrand AV, Roberts PD, Willoughby ML, Bollum FJ. Detection of leukaemic lymphoblasts in the cerebrospinal fluid by immunofluorescence for terminal transferase. Lancet $1980 ; 1: 1144$.

23 Janossy G, Thomas JA, Pizzolo G, Granger S, McLaughlin J, Habeshaw J, Stansfield AG, Sloane J. Immunohistological diagnosis of lymphoproliferative diseases using selected combinations of antisera and monoclonal antibodies. Br J Cancer 1980;42:1-20.

${ }^{24}$ Janossy G, Bollum FJ, Bradstock KF, Ashley J. Cellular phenotypes of normal and leukaemic haemopoietic cells determined by selected antibody combinations. Blood 1980;56:430-41.

${ }^{25}$ Bradstock KF, Hoffbrand AV, Ganeshaguru K, et al. Terminal deoxynucleotidyl transferase expression in acute non-lymphoid leukaemia-an analysis by immunofluorescence. $\mathrm{Br} J$ Haematol in press.

${ }^{26}$ Srivastava BIS, Khan SA, Minowada J, Henderson ES, Rakowski I. Terminal deoxynucleotidyl transferase activity and blast cell characteristics in adult acute leukemias. Leuk Res 1980;4:209-15.

27 Greaves MF, Verbi W, Reeves BR, et al. 'Pre-B' phenotypes in blast crisis of $\mathrm{Ph}^{\prime}$ positive CML: Evidence for a pluripotential stem cell "Target". Leuk Res $1979 ; 3: 181-91$.

28 Janossy G, Woodruff RK, Paxton A, et al. Membrane marker and cell separation studies in $\mathbf{P h}^{\prime}$ positive leukemia. Blood 1978;51:861-77.

${ }^{29}$ Donlon JA, Jaffe ES, Braylan RC. Terminal deoxynucleotidyl transferase activity in malignant lymphomas. New Engl J Med 1977;297:461-4.

${ }^{30}$ Habeshaw JA, Catley PF, Stansfield AG, Ganeshaguru K, Hoffbrand AV. Terminal deoxynucleotidyl transferase activity in lymphoma. $\mathrm{Br} J$ Cancer $1979 ; 39: 566-9$.

${ }^{31}$ Giblett ER, Anderson JE, Cohen F, Pollara B, Meuwissen HJ. Adenosine deaminase deficiency in two patients with severely impaired cellular immunity. Lancet 1972; 2:1067-9.

${ }^{32}$ Barton R, Martiniuk F, Hirschhorn R, Goldschneider I. The distribution of adenosine deaminase among lymphocyte populations in the rat. J Immunol 1979;122: 216-20.

${ }^{33}$ Mitchell B, Mejias E, Daddowa PE, Kelley WN. Purinogenic immunodeficiency diseases: Selective toxicity of deoxyribonucleosides for T cells. Proc Natl Acad Sci 1978;75:5011-4.

${ }^{34}$ Carson DA, Kaye J, Matsumoto S, Seemiller JE, Thompson L. Biochemical basis for the enhanced toxicity of deoxyribonucleosides toward malignant human T cell lines. Proc Natl Acad Sci 1979;66:2430-3.

${ }^{35}$ Wortmann RL, Mitchell BS, Edwards NL, Fox IH. Biochemical basis for differential deoxyadenosine toxicity to lymphoblast-T and lymphoblast-B-Role for 5' nucleotidase. Proc Natl Acad Sci 1979;76:2434-7.

${ }^{36}$ Taheri MR, Wickremasinghe RG, Hoffbrand AV. Alternative metabolic fates of thymine nucleotides in human cells. Biochem $J$ in press.

${ }^{37}$ Johnston JM, Kredich NM. Inhibition of methylation by adenosine in adenosine deaminase-inhibited, phytohemagglutinin-stimulated human lymphocytes. $J$ Immunol 1979;123:97-103.

${ }^{38}$ Russell N, Prentice HG, Lee N, et al. Studies on the biochemical sequelae of therapy in Thy-acute lymphoblastic leukaemia with the adenosine deaminase inhibitor $2^{\prime}$ deoxycoformycin. Submitted to Br J Haemat.

${ }^{39}$ Smyth JF, Harrap KR. Adenosine deaminase activity in leukaemia. Br J Cancer 1975;31:544-9.

40 Meier J, Coleman MS, Hutton JJ. Adenosine deaminase activity in peripheral blood cells of patients with haematological malignancies. $\mathrm{Br} J$ Cancer 1976;33: 312-9.

${ }^{41}$ Silber R, Quagliata F, Conklyn M, Gottesman J, Hirschhorn $R$. Adenosine deaminase activity in chronic lymphocytic leukaemia-Relationship to B-cell and T-cell subpopulations. J Clin Invest 1976;57:756.

42 Ramot B, Brok-Simoni F, Barnea N, Bank I, Holtzmann F. Adenosine deaminase (ADA) activity in lymphocytes of normal individuals and patients with chronic lymphatic leukaemia. Br J Haematol 1977;36:67-70.

${ }^{43}$ Coleman MS, Greenwood MF, Hutton JJ, Holland P, Lampkin B, Krill C, Kastelic JE. Adenosine deaminase, terminal deoxynucleotidyl transferase (TdT) and cell surface markers in childhood acute leukemia. Blood 1978;52:1125-31.

${ }^{44}$ Smyth JF, Poplack DG, Holiman BJ, Leventhal BG, Yarbro G. Correlation of adenosine deaminase activity with cell surface markers in acute lymphoblastic leukemia. J Clin Invest 1978;57:710-2.

45 Chechik BE, Rao J, Greaves MF, Hoffbrand AV. Human thymus/leukaemia-associated antigen (a low-molecular weight form of adenosine deaminase) and the phenotype of leukaemic cells. Leuk Res 1980;4:343-9.

${ }^{46}$ Ganeshaguru $K$, Lee $N$, Llewelin $P$, et al. Adenosine deaminase concentrations in leukaemia and lymphoma: Relation to cell phenotypes. Leuk Res submitted.

${ }^{47}$ Smyth JF, Young RC, Young DM. In vivo toxicity to lymphoid tissue by $2^{\prime}$ deoxycoformycin. Cancer Chemo Pharmacol 1978;1:49-51.

${ }^{48}$ Mitchell BS, Koller CA, Heyn R. Inhibition of adenosine deaminase activity results in cytotoxicity to $\mathrm{T}$ lymphoblasts in vivo. Blood 1980;56:556-9.

49 Koller CA, Mitchell BS, Grever MR, Mejias E, Malspeis L, Metz EN. Treatment of acute lymphoblastic leukemia with 2' deoxycoformycin: clinical and biochemical consequences of adenosine deaminase inhibition. Cancer Treat Rep 1979;63:11-2.

${ }^{50}$ Giblett ER, Ammann AJ, Wara DW, Sandman R, Diamond LK. Nucleoside phosphorylase deficiency in a child with severely defective $T$ cell immunity and normal B cell immunity. Lancet 1975; 1:1010-3.

51 Cohen A, Gudas LJ, Ammann AJ, Staal GEJ, Martin DW. Deoxyguanosine triphosphate as a possible toxic metabolite in immunodeficiency associated with purine nucleoside phosphorylase deficiency. J Clin Invest 1978; 61:1405-9.

52 Blatt J, Reaman GH, Levin N, Poplack DG. Purine nucleoside phosphorylase activity in acute lymphoblastic leukemia. Blood 1980;56:380-2.

${ }^{53}$ Borgers M, Verhaegen $\mathrm{H}$, De Brabander M, De Cree J, De Cock W, Horne F, Geuens G. Purine nucleoside phosphorylase in chronic lymphocytic leukemia (CLL). Blood 1978;52:886-95.

${ }^{54}$ Ludwig H, Kuzmits R, Pietschmann H, Muller MM. Enzymes of the purine interconversion system in chronic lymphatic leukemia: Decreased purine nucleoside phosphorylase and adenosine deaminase activity. Blut 1979;39:309-17.

55 Reinherz EL, Schlossman SF. The differentiation and function of human T lymphocytes-review. Cell 1980; 19:821-7.

${ }^{56}$ Kung PC, Goldstein G, Reinherz EL, Schlossman SF. Monoclonal antibodies defining distinctive human $T$ 
cell surface antigens. Science 1979;206:347-50.

${ }^{57}$ Greaves MF. Analysis of lymphoid phenotypes in acute leukaemia: their clinical and biological significance. Cancer Treat Rep in press.

${ }^{5}$ Crawford DH, Francis G, Edwards AF, et al. Reactivity of monoclonal antibodies with human myeloid precursor cells. (in preparation).

5. Ritz J, Pesando JM, Notis-McConarty D, Lazarus $H$, Schlossman SF. A monoclonal antibody to human acute lymphoblastic leukaemia antigen. Nature 1980;283:583.

${ }^{60}$ Sieff C, Robinson T, Greaves MF. Ia-like antigens on human BFUc. Nature in press.

${ }^{61}$ Janossy G, Tidman N, Papageorgiou ES, Kung PC, Goldstein G. Distribution of T lymphocyte subsets in the human bone marrow and thymus-an analysis with monoclonal antibodies. $J$ Immunol submitted.

62 Goldschneider I, Ahmed A. Bollum FJ, Goldstein AL. Induction of TdT and Ly antigens in mouse bone marrow and spleen cells by thymosin: demonstration by fluorescence. $J$ Immunol in press.

${ }^{63}$ Reinherz EL, Kung PC. Goldstein G, Levey RH, Schlossman SF. Discrete stages of human intrathymic differentiation: analysis of normal thymocytes and leukaemic blasts of T lineage. Proc Natl Acad Sci USA 1980;77: 1588-92.

"1 Bradstock KF, Janossy G, Pizzolo G, 't al. Subpopulations of normal and leukemic human thymocytes:
An analysis with the use of monoclonal antibodies. $J$ Natl Cancer Inst in press.

${ }_{65}$ Kamoun M, Martin PJ, Hansen JA, Brown MA, Nowinski RC. Identification of monoclonal antibody of a p5s surface polypeptide on human T lymphocytes associated with the E-rosette receptor. (in preparation).

${ }^{66}$ Royston I, Majda T, Baird S, Meserve B, Griffiths B. Monoclonal antibody specific for human $T$ lymphocytes: identification of normal and malignant $\mathrm{T}$ cells. Annual Conf Amer Haematol 1979.

6: McMichael AJ, Pilch JR, Galfre G, Mason DY, Fabre JW, Milstein C. A human thymocyte antigen defined by a hybrid myeloma monoclonal antibody. Europ Immunol 1979;9:205-10.

${ }^{6 \times}$ Beverley PCL, Linch D, Delia D. Isolation of human haemopoietic cells using monoclonal antibodies. Nature 1980;287:232-3.

${ }^{69}$ Netzel B, Haas RJ, Rodt H, Kolb HJ, Thierfelder S. Immunological conditioning of bone marrow for autotransplantation in childhood acute lymphoblastic leukaemia. Lance't 1980;1:1330-2.

Requests for reprints to: Professor AV Hoffbrand, Department of Haematology, The Royal Free Hospital, Pond Street, Hampstead, London NW3 2QG. 